\title{
„Żyje SiĘ TYlKo chWilę" — czy Halina Poświatowska zMarŁa MŁodo?
}

\author{
„Żyje się tylko chwilę \\ a czas \\ jest przeźroczystą perłą \\ wypełnioną oddechem" \\ Halina Poświatowska
}

Twórczość poetycka żyjącej w latach 1935-1967 autorki Ody do rąk nadal budzi żywe zainteresowanie badaczy literatury. W maju 2014 roku ukazała się publikacja Uparte serce. Biografia Poświatowskiej autorstwa Kaliny Błażejowskiej. W zapowiedzi tej książki na stronie internetowej wydawnictwa widniało zdanie „Zmarła w wieku zaledwie 32 lat"1.

We wszystkich opracowaniach o poetce pojawiają się informacje o tym, że od dziesiątego roku życia miała wadę serca i przeszła dwie operacje tego narządu. Była wciąż zagrożona nagła, przedwczesną śmiercią, której się bała, czemu dawała wyraz w swych wierszach, listach i autobiograficznej Opowieści dla przyjaciela (1967). Badacze poezji Haliny Poświatowskiej skupiali się na motywach jej wierszy, podkreślając przebijającą z nich wolę i pasję życia, a także erotyzm². Obecne studium ma udowodnić, że gdyby nie wada serca, być może nigdy nie zaczęłaby tworzyć.

O sercu i stanie zdrowia Poświatowska nieraz wspominała w wierszach, choćby tych opublikowanych w tomie Oda do rack (1966):

delikatnie niosę moje serce

jak obciętą głowę świętego Jana

\footnotetext{
* Ewa Joanna Marczak — absolwentka filologii polskiej z kulturoznawstwem Akademii Pomorskiej w Słupsku, podyplomowego studium dziennikarstwa na Uniwersytecie im. Adama Mickiewicza w Poznaniu oraz Pomaturalnego Studium Zawodowego Zaocznego w Koszalinie, filia Centrum Edukacji Bibliotekarskiej, Informacyjnej i Dokumentacyjnej im. H. Radlińskiej w Warszawie na kierunku bibliotekarstwo. Od 2006 roku dziennikarka gazety „Miasto” w Koszalinie i współpracowniczka diecezjalnej edycji ogólnopolskiego tygodnika opinii „Gość Niedzielny”. Od 2013 roku doktorantka Uniwersytetu Gdańskiego (rozprawa doktorska o wartościach chrześcijańskich w twórczości Zofii Kossak).

${ }^{1}$ K. Błażejowska, Uparte serce. Biografia Poświatowskiej [online], Kraków 2014, dostęp 20 maja 2014 dostępny: <www.znak.com.pl/kartoteka,ksiazka,4488,>.

${ }^{2}$ Zob. M. Szułczyńska, „Nie popetnitam zdrady”. Rzecz o Halinie Poświatowskiej, Bydgoszcz 1995, s. 11;

G. Borkowska, Nierozważna i nieromantyczna. O Halinie Poświatowskiej, Kraków 2001, s. 5.
} 
ziemia tańczy pode mną

moje serce jest amebą

wydłużającą się bez końca

żyjątkiem ${ }^{3}$

W tomie Jeszcze jedno wspomnienie, wydanym w 1968 roku już po śmierci poetki, znalazły się wiersze, które napisała kilka lat wcześniej, przed pierwszą operacją. W utworze Moje serce jest władca absolutnym ukazała, jak bardzo wada serca zdominowała jej życie:

moje serce jest władcą absolutnym

ach jak ono się panoszy

przesłania mi cały świat ${ }^{4}$

Poetka miała poczucie, że może umrzeć wcześniej niż jej rówieśnicy. Stąd częsty w jej utworach motyw kruchości ludzkiej egzystencji i nieuchronności przemijania. Doskonale ukazuje to wiersz Koniugacja:
ja minę
ty miniesz
mijamy $^{5}$

Od początku choroby nie opuszczała Poświatowskiej świadomość zagrożenia śmiercią, którą w jej wierszach symbolizował ptak:

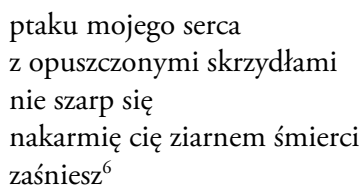

Zamiłowanie do nauki, a także do czytania utworów narodowych wieszczów sprawiło, że Poświatowska zaczęła tworzyć poezję jeszcze w dzieciństwie. Wspomniała o tym w autobiografii:

Matka mówi, że czytałam książki, wertowałam podręczniki szkolne, uczyłam się na pamięć wierszy i próbowałam pisać własne. Niedościgłym wzorem był Mickiewicz i Słowacki. Pisałam wiersze rymowane trzynasto- i jedenastozgłoskowe, próbowałam także pisać sonety, a kiedy zdawało mi się, że posiadłam tę sztukę, dobierałam rymów potrójnych i budowałam oktawy

\footnotetext{
${ }^{3}$ H. Poświatowska, ${ }^{* * *}$ (delikatnie niosę moje serce), [w:] taż, Wiersze wybrane, wstęp i wyb. J. Zych, Warszawa 1987, s. 141.

${ }^{4}$ Taż, ${ }^{* * *}$ (moje serce jest wtadca absolutnym) [w:] Tamże,s.286.

${ }^{5}$ Taż, Koniugacja, [w:] Tamże, s. 328.

${ }^{6}$ Taż, Ptaku mojego serca, [w:] Tamże, s. 287.

${ }^{7}$ Tamże, s. 37.
} 
Zainteresowanie polską poezją i literaturą pomogła Poświatowskiej rozwinąć matka, Stanisława Mygowa, wspierająca poetkę przez całe jej życie. Z mamą łączyła literatkę bardzo silna więź. Lektura stała się formą terapii, bo odsuwała myśli dziewczynki od jej poważnego stanu.

\section{CHOROBA LUDZI STARYCH}

Według Stownika jezyka polskiego, „Młodość to okres życia między dzieciństwem a dojrzałością"8. Ten czas kojarzy się z bardzo dobrym stanem zdrowia, energią, buntem i beztroską. Przyszła poetka w dzieciństwie przeżyła II wojnę światową, której skutkiem była poważna choroba — angina. Powikłaniem po jej przebyciu były zapalenie stawów, zapalenie wsierdzia i na koniec wada zastawki dwudzielnej połączona z arytmią, czyli niemiarowym biciem serca. Te problemy kardiologiczne spowodowały, że życie Poświatowskiej przypominało egzystencję osoby starszej. Dziewczyna, a potem kobieta, musiała prowadzić oszczędny tryb życia, co oznaczało, że nie powinna się męczyć tańcami, jazdą na rowerze, bieganiem, wchodzeniem po schodach. Poza tym stale przyjmowała leki.

Uznaje się za coś oczywistego, że problemy zdrowotne, zwłaszcza kardiologiczne, dotykają osób starszych. Wady serca — wrodzone lub nabyte — u dzieci, czy młodych dorosłych nawet obecnie budzą zdziwienie i niedowierzanie, o czym świadczą wypowiedzi osób z takimi problemami dostępne między innymi na forum internetowym Fundacji Serce Dziecka. Magda, która urodziła się ze złożoną wadą serca, pisząca na forum jako gwiazdeczka69, w dniu 12 maja 2008 roku, mając 22 lata, stwierdziła w czasie oczekiwania na trzecią operację:

I teraz znów strach, ból i taka wielka niewiadoma — ja nie umiem się skupić na niczym, szkoła mnie dobija i świergotanie koleżanek o tym, gdzie jadą na wakacje, o ich planach i marzeniach. Ja czuję się jak zawieszona w próżni — żadnych planów, z powolnym czekaniem na pójście do szpitala. I znowu miesiąc drenów, a po drodze nerwy — biorąc pod uwagę, że przeżyję tę operację. A na dokładkę wykładowcy — jeden mówi: „Dobrze, że pani mi pokazała swoje papiery choroby, bo tak bym nie uwierzył. Już miałem powiedzieć: niech pani wymyśli inną wymówkę, bo na chorobę serca mnie pani nie naciągnie. Przecież wiadomo, że ludzie młodzi na serce nie chorują”. I śmiech?.

Osoby z wadami serca są bohaterami literatury współczesnej dla młodzieży. Przykładem tego jest powieść Marii Nurowskiej Reszta świata (1981), której główną bohaterką jest siedemnastoletnia Anna, mająca ubytek przegrody międzykomorowej (VSD), powstały w prenatalnym okresie jej życia. Decyzja o poddaniu się operacji była jej pierwszym krokiem ku dorosłemu życiu. Z powodu wieku zgodę na operację musiał pod nieobecność matki podpisać jej ojciec:

\footnotetext{
${ }^{8}$ Stownik jezyka polskiego, t. 3, red. M. Bańko, Warszawa 2007, s. 1.

${ }^{9}$ Gwiazdeczka69 [online], [autor tematu: hsynowiec, temat: Teraz ja mam doła, wątek Różności w dziale Wolna dyskusja] dostęp: 7 października 2013, dostępny: <www.forum.sercedziecka.org.pl/viewtopic. php?p=26552\&highlight=\#26552,>.
} 
— Chcę, żebyś podpisał zgodę na operację — wyrzuciła z siebie jednym tchem. [...]

— A ty byś podpisała? - spytał patrząc jej prosto w oczy.

— Tak — odparła wytrzymując to spojrzenie.

— Taka jesteś zdecydowana. Żadnych wątpliwości. Jesteś jeszcze niedojrzała.

— Mylisz się. To ja podjęłam decyzję w swojej sprawie. Ty ją tylko musisz potwierdzić, bo przepis mówi, że nie mogę sama decydować, bo jestem niepełnoletnia ${ }^{10}$.

Poświatowska także pragnęła przejść operację, mimo że była ona bardzo ryzykowna. Poetka wolała jednak poddać się niebezpiecznemu zabiegowi na odległym kontynencie, niż nadal się męczyć. Oświadczyła to polskiemu lekarzowi, pracującemu w szpitalu Hahnemann w Filadelfii ${ }^{11}$.

W przewodniku po młodości Weroniki i Mikołaja Kozakiewiczów znajduje się informacja, że, według danych GUS z 1970 roku, śmierć w wyniku chorób serca u młodzieży to zaledwie promil wszystkich zgonów. Trudno w to uwierzyć, zważywszy ówczesną dużą śmiertelność dzieci z wrodzonymi wadami serca. Zarówno w latach 70., jak i obecnie, 1 procent dzieci przychodzących na świat w Polsce ma takie wady. Zaniżone statystyki wynikały prawdopodobnie $\mathrm{z}$ tego, że dzieci umierały we wczesnym dzieciństwie z nieznanych wówczas przyczyn. Ta sama publikacja podaje, że wśród ludzi dorosłych, powyżej 30. roku życia, choroby serca stanowiły wówczas drugą, po nowotworach złośliwych, przyczynę ich śmierci ${ }^{12}$.

Nabyta wada serca uczyniła z Poświatowskiej osobę niepełnosprawną. To pojęcie jest obecnie zawężane do osób poruszających się o kulach, na wózku inwalidzkim, niewidomych czy niesłyszących. Tymczasem wada serca, którą miała poetka, znacznie ograniczała jej poruszanie się i wykonywanie codziennych czynności. Duszności, szybkie męczenie się, zaburzenia rytmu serca sprawiały, że dziesięcioletnia Helena ${ }^{13}$ Myga nie mogła ani chodzić do szkoły, ani bawić się z innymi dziećmi. Musiała dużo odpoczywać. Uczyła się miesiącami w domu, pomagała w nauce odwiedzającym ją koleżankom ${ }^{14}$.

\section{DelikATNIE NiOSĘ MOJE SERCE}

Poświatowska żyła dokładnie 32 lata, 5 miesięcy i 2 dni. Dla człowieka zdrowego to niewiele, więc w powszechnej opinii poetka umarła młodo. Czas biegnie jednak inaczej z perspektywy osoby chorej, która wie, że każda chwila jej życia może być ostatnią.

${ }^{10}$ M. Nurowska, Reszta świata, Warszawa 1981, s. 246-248.

${ }^{11}$ H. Poświatowska, Opowieść dla przyjaciela, Kraków 1996, s. 115.

${ }^{12}$ W. i M. Kozakiewicz, Przewodnik po mtodości, Warszawa 1986, s. 29-30.

${ }^{13}$ Takie imię zostało zapisane w akcie urodzenia. Zmianę imienia zalecił kapłan, mający udzielić sakramentu chrztu świętego, bo chrześcijanin powinien nosić imię jakiegoś świętego lub błogosławionego. Poetka zmieniła imię urzędowo w 1961 roku Te informacje i kserokopia skróconego odpisu aktu urodzenia znajdują się w książce M. Szułczyńskiej „Nie popetniłam zdrady”. Rzecz o Halinie Poświatowskiej, Bydgoszcz 1995, s. 25-26.

${ }^{14}$ Tamże, s. 42. 
Główne nieszczęście autorki Koniugacji polegało na tym, że urodziła się za wcześnie, by medycyna mogła jej skutecznie i trwale pomóc. Władysław Ryszard Szeląg, znawca poezji Poświatowskiej, stwierdził, że była ona „spóźnioną ofiarą II wojny światowej" 15 , bo to z powodu przebywania w wilgotnej piwnicy w czasie niemieckiego bombardowania zachorowała na anginę.

Serce ludzkie składa się z 4 zastawek: dwudzielnej, między lewym przedsionkiem a lewą komorą; trójdzielnej, między prawym przedsionkiem a prawą komorą; aortalnej, między lewą komorą a aortą, i płucnej, między prawą komorą a tętnicą płucną. Organ ten jest bardzo podatny na infekcje. Anomalie w jego budowie i funkcjonowaniu są różnego typu. Pierwsze z nich powstają w pierwszych tygodniach ciąży:

Pod pojęciem wady serca rozumie się [...] nieprawidłową czynność zastawek przedsionkowo-komorowych lub komorowo-tętniczych, nieprawidłową drogę lub kierunek przepływu krwi przez serce lub naczynie krwionośne. [...] Wady serca wrodzone powstają w okresie życia płodowego, a wady nabyte rozwijają się po urodzeniu u dziecka lub osoby dorosłej ${ }^{16}$.

Niedomykalność oznacza, że w chwili skurczu płatki zastawki się z sobą nie łączą, powodując, że krew cofa się z lewej komory do lewego przedsionka. Lewa część serca jest przeciążona, co prowadzi do migotania lewego przedsionka i wzrostu ciśnienia płucnego. Dochodzi do obrzęku płuc i niewydolności krążenia ${ }^{17}$. Niedomykalność zastawki dwudzielnej powstała u Poświatowskiej w wyniku zapalenia wsierdzia. Jest to: „proces zapalny tkanek wyściełających jamy serca, głównie zaś w okolicy nitek ścięgnistych i zastawek"18.

Dopiero pół wieku po śmierci poetki kardiolodzy opisali w miarę dokładnie, na czym polegała wada Haśki. W biografii poetki autorstwa Błażejowskiej uczynił to jeden z wybitnych kardiochirurgów, prof. Antoni Dziatkowiak z Krakowa:

[...] można wnioskować, że po ostrej chorobie reumatycznej z zapaleniem wsierdzia doszło do zbliznowacenia wsierdzia zastawkowego na zastawce mitralnej [...] Często zdarza się, że proces zapalny powoduje jednocześnie zwężenie ujścia mitralnego oraz niedomykalność. Wtedy mamy do czynienia ze złożoną wadą mitralną: zwężeniem i z niedomykalnością — z przewagą jednej lub drugiej izolowanej wady. U Poświatowskiej była to złożona wada mitralna z przewagą niedomykalności ${ }^{19}$.

W latach 40. i 50. XX wieku kardiochirurgia dopiero się rozwijała, nie tylko w naszym kraju, ale i na świecie. W polskich szpitalach nie było maszyny do krążenia pozaustrojowego, pozwalającej na zatrzymywanie akcji serca i wymianę zastawki. Tymczasem niedomykalność zastawki dwudzielnej była i jest jedną z najczęstszych nabytych

15 B. Pawłowicz, Halina Poświatowska: Poetka, która koi [online], dostęp: 17 września 2013, aktualizacja 25. 12. 2011, dostępny: <www.kobieta.newsweek.pl/ukojenie-poswiatowskiej,57802,1,1.html 07-05-2010>.

${ }^{16}$ Wady serca u dorostych, red. M. Olszowska, Poznań 2011, s. 13.

${ }^{17}$ Tamże, s. 112.

${ }^{18}$ Mała encyklopedia zdrowia, red. T. J. Wolański, Warszawa 1957, s. 215.

${ }^{19}$ K. Błażejowska, dz. cyt., s. 327. 
wad serca. Obecnie, gdy stopień niedomykalności jest duży, zastawka jest wymieniana na biologiczną, ludzką lub zwierzęcą, albo sztuczną, czyli mechaniczną. Warto zaznaczyć, że poza tradycyjnymi operacjami z otwarciem klatki piersiowej, obecnie przeprowadza się operacje mało inwazyjne lub zabiegi przezskórne, z nakłuciem tętnicy lub żyły głównie udowej. Kardiolodzy zauważają jednak, że ten ostatni sposób, choć znacznie mniej obciążający pacjenta, nie daje tak dobrego efektu korekcji tej wady serca, jak operacje, bo dopiero po otwarciu klatki piersiowej można nie tylko dokładniej ocenić stan narządu, ale i precyzyjniej umieścić implant zastawki, co może zapobiec jej szybkiej degeneracji ${ }^{20}$.

Mimo niemożności przebycia szybkiej operacji Poświatowska żyła z wadą serca kilkanaście lat. Jej stan się regularnie pogarszał, mimo wielu pobytów w szpitalach i sanatoriach. W połowie XX wieku u pacjentów z wadami serca stosowano leczenie zachowawcze:

Może do żadnego układu czy narządu nie odnosi się tak zasada o bezwzględnym zachowaniu równowagi psychicznej jak właśnie do narządu krążenia. Wiemy, że u chorych na serce przykra wiadomość, gniew, a nawet przykre słowo może spowodować wybitne pogorszenie stanu zdrowia. Serce jest narządem, które najczulej i najszybciej reaguje na wszystkie bodźce (przyśpieszenie akcji serca pod wpływem emocji itd.). Stąd w zapobieganiu chorobom układu krążenia eliminowanie emocji negatywnych odgrywa pierwszorzędną rolę ${ }^{21}$.

Zgodnie z tymi wskazówkami lekarze opiekujący się Poświatowską zalecali jej jak najspokojniejszy tryb życia, choć pewnie przypuszczali, że u dziecka to prawie niemożliwe. Jeden z nich dawał jej takie rady po kolejnych tygodniach leżenia: „Nie wolno ci biegać i nie wolno jeździć na rowerze, nie wolno ci się męczyć” $[\ldots]^{22}$. Chora kobieta po latach nie kryła, że bardzo chciała się uczyć w szkole, będącej miejscem przebywania ludzi zdrowych. Niestety, w połowie XX wieku siedziby placówek oświatowych nie były przystosowane dla uczniów z wadami serca. Nie było wind, więc piętnastoletnia dziewczyna ryzykowała życiem, wspinając się po schodach:

Szkoła mieściła się w okazałym czteropiętrowym gmachu, moja klasa znajdowała się na czwartym piętrze. Codziennie wspinałam się na schody dysząc ciężko, ręką przyciskałam silnie bijące serce. $\mathrm{Na}$ pierwszej godzinie lekcyjnej słowa nauczyciela nie docierały do mnie, zajęta byłam bez reszty uspokajaniem rozkołysanego serca. Starałam się opanować duszność, wciągając głęboko powietrze, próbowałam hamować spłoszone myśli. Czy zmęczenie minie? Czy będę mogła chodzić do szkoły? Jeśli matka odgadnie, jak bardzo męczy mnie wchodzenie na schody, na pewno zabroni mi tu przychodzić23!

Dzięki pierwszej operacji w 1958 roku, którą poetka przeszła w wieku 23 lat w USA, mogła w tym kraju studiować i podróżować po nim. Operacja przedłużyła jej

\footnotetext{
${ }^{20}$ Wady serca u dorostych..., s. 133-144.

${ }^{21}$ Mata encyklopedia zdrowia, s. 218.

${ }^{22}$ H. Poświatowska, Opowieść dla przyjaciela, s. 37.

${ }^{23}$ Tamże, s. 39-40.
} 
życie o 9 lat. Wcześniej lekarze sądzili, że będzie żyć rok, może półtora roku. Tydzień po tej operacji Poświatowska napisała do matki:

Podobno miałam zupełnie zniesioną zastawkę, rozszerzenie jakiegoś tam czwartego stopnia i że oni jeszcze tego nie operują. Przemyciłam się na operację dzięki temu, że badanie było niedokładne. A dopiero gdy mnie ładnie rozkroili — przyszedł Nichols (najlepszy chirurg, który mnie operował). [...] Leszek mówi, że z tą zastawką żyłabym najwyżej rok, lub półtora, a potem udusiłabym się. Genialny Nichols przyszył ją czterema ściegami na amen nylonem ${ }^{24}$.

Do pracy chciała też przywyknąć sama poetka. Z początku nie dowierzała temu, że w ogóle taką poważną operację przeżyła. Dziwiła się, że serce już nie jest powiększone, że bije spokojniej i ona nie odczuwa właściwie jego pracy. Zanim wyszła ze szpitala, narodziła się w niej myśl, by nadal robić to, co do tej pory było tylko wypełnianiem czasu choroby. Poświatowska, mająca już za sobą publikacje wierszy w prasie, chciała nie tylko dalej je pisać, ale marzyła o poważnej nauce. Pragnęła nadrobić czas spędzony w szpitalach i sanatoriach. Podzieliła swoje życie na to przed operacją i po niej. Lekarze przestrzegali poetkę, że efekt operacji nie jest trwały, więc nadal powinna się oszczędzać:

[...] choroba rozwijała się powoli, ograniczając coraz bardziej możliwości poruszania się i działania. Patrzyliśmy na to bezsilni, gdyż schorzenie było nieodwracalne pomimo operacji $[\ldots]^{25}$.

To było jednak dla Poświatowskiej bardzo trudne. Tłumiona latami energia popychała ją do aktywności umysłowej i fizycznej. Tak jak wcześniej, tym bardziej po operacji, poetka nie słuchała zbytnio lekarzy. Miała 23 lata, chciała zacząć w pełni samodzielne życie, zapomnieć o pobytach w szpitalach i sanatoriach. Jej zapał do nauki nie minął, a lepsza kondycja fizyczna wpłynęła na decyzję o studiach w USA. Z pomocą dalekiego kuzyna i przy wsparciu Polskiego Instytutu Naukowego kobieta wysłała do różnych uczelni podania o stypendium, dołączając przysłane z Polski egzemplarze tomiku wierszy ${ }^{26}$ i swoją historię. Dostała trzy pozytywne odpowiedzi. Ostatecznie wybrała ofertę żeńskiego Smith College w Northampton, w stanie Massachusetts.

Po dwóch latach zaczęła jej dokuczać tęsknota za Polską. Pojawiły się ponownie problemy z sercem, na przykład w czasie jazdy na rowerze z przyjaciółkami z uczelni.

Jadę coraz szybciej. Yasuko [imię koleżanki z Japonii — przyp. E.M.] nie może nadążyć. Nie słucham jej nawoływań, przyspieszam jeszcze i czuję, jak moje serce zaczyna niebezpiecznie drgać. Znajoma duszność podpełza mi pod gardło. Chwytam oddech szeroko otwartymi ustami, z satysfakcją nasłuchując głuchych, nierównych uderzeń.

— Więc jednak nie jest zdrowe — myślę z ulgą i uśmiecham się do Yasuko, która zdołała mnie wreszcie dogonić27.

\footnotetext{
${ }^{24}$ Taż, ja minę, ty miniesz..., [w:] Tamże, s. 174-176.

${ }^{25}$ Tamże, s. 151. Wspomnienie lekarza, Jerzego Lisiewicza, współpracownika prof. Juliana Aleksandrowicza, o poetce.

${ }^{26}$ Wydany w 1958 roku debiutancki tomik Hymn batwochwalczy.

${ }^{27}$ Tamże, s. 175.
} 
Dlaczego mająca tyle życiowych planów kobieta poczuła ulgę z powodu powrotu niepokojących objawów, które uniemożliwiały jej normalne funkcjonowanie? Małgorzata Szułczyńska przywołała jeden z listów poetki do prof. Juliana Aleksandrowicza. Poświatowska wyznała w nim: „Brakuje mi walki ze śmiercią i w braku śmierci walczę z sobą i życiem"28. Biografka poetki dodała:

Halina tęskniła za atmosferą szpitalną, pełną bólu i niepokoju, tęskniła, ponieważ taka atmosfera była jej potrzebna. Potrzebna do życia — i do tworzenia [...] Tak, bez owego lęku, bez niepewności, wprawiającej cały organizm w drżenie, nie byłaby sobą ${ }^{29}$.

Mimo pogarszającego się stanu zdrowia, na co wpływ miały przeziębienia i choroby, a także zmiany pogody, Poświatowska nie rezygnowała z aktywnego trybu życia. Lato 1962 roku, już jako studentka ostatniego roku Wydziału Filozoficzno-Historycznego krakowskiego uniwersytetu, spędziła w Bieszczadach, często urządzając wielokilometrowe piesze wycieczki ${ }^{30}$. W kolejnych latach coraz częściej musiała przebywać w szpitalach i sanatoriach. Znowu leżała tygodniami w łóżku. Jednak także wtedy nie rezygnowała z nauki, mimo rygorystycznych zakazów prof. Aleksandrowicza. Chciała mu udowodnić swoją wartość, bo ulubiony lekarz stwierdził kiedyś, że „tyle człowiek wart, ile w życiu osiagną̧, ile po sobie pozostawił”31.

\section{PodSUMOWANiE}

Lektura biografii poetki uświadamia, jak bardzo intensywne było jej życie, ile ta kobieta dokonała mimo zdrowotnych przeszkód. W czasie studiów w USA i w Polsce uczyła się między innymi filozofii i ekonomii, poznawała języki obce: angielski, francuski, serbsko-chorwacki. Sama prowadziła ćwiczenia ze studentami na Uniwersytecie Jagiellońskim w Krakowie. Zaczęła robić doktorat, którego, niestety, nie ukończyła z powodu pogarszającego się stanu zdrowia i śmierci wkrótce po drugiej operacji, którą przeszła w Warszawie w 1967 roku. To bardzo wiele, nawet dla zdrowego, młodego człowieka $^{32}$. Elżbieta Hurnikowa podkreśliła kruchość istnienia Poświatowskiej.

„[...] żyła zbyt krótko, w ciągłej obawie o to, że każda chwila może być ostatnia. Gdyby jednak życie mierzyć intensywnością przeżyć, okazałoby się, że Poświatowska swoimi doświadczeniami i siłą przeżywania obdzielić mogłaby kilka ludzkich istnień"33.

Dwadzieścia jeden lat z poważną wadą serca to bardzo długi okres, biorąc pod uwagę ówczesny stopień rozwoju kardiochirurgii i mimo wszystko bardzo aktywny tryb życia poetki. Trzeba pamiętać, że serce z wadą anatomiczną, która utrudnia jego

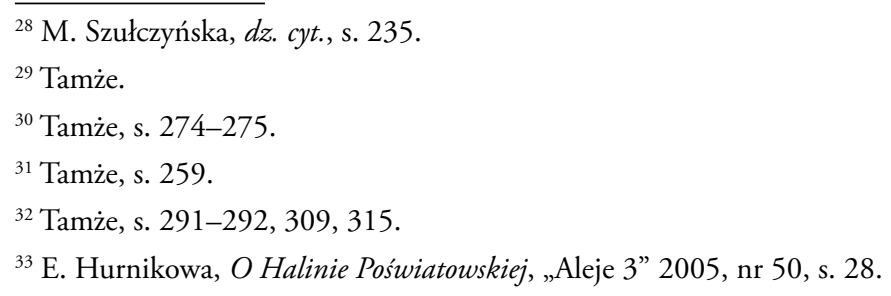


pracę, zużywa się szybciej, niż serce osoby zupełnie zdrowej. Poświatowska żyła więc bardzo długo, znacznie dłużej, niż przypuszczali lekarze. Prof. Dziatkowiak zaznaczył, że poetka u schyłku swego nader aktywnego życia była w bardzo złym stanie:

W 1967 roku doc. Wacław Sitkowski wykazał maksimum odwagi i miłosierdzia, podejmując się ponownej operacji serca po Amerykanach i wymiany zniszczonej zastawki mitralnej na sztuczną. Był to akt rozpaczy pacjentki w ekstremalnie ciężkim stanie krążenia i akt odwagi lekarza. [...] Chora miała wieloletnie zaburzenia krążenia płucnego (nadciśnienie płucne jako następstwo wady mitralnej). Dlatego też i obecnie taka operacja byłaby obarczona bardzo wysokim ryzykiem około 25 proc. śmiertelności ${ }^{34}$.

Obecnie z wadami serca, zarówno wrodzonymi, jak i nabytymi, w Polsce żyje ponad sto tysięcy dorosłych. Wiele z nich, podobnie jak Poświatowska, ujawniło swoje uzdolnienia i realizuje je w różnych dziedzinach sztuki, na przykład Robert „Litza” Friedrich jest muzykiem z zespołów Acid Drinkers i Arka Noego, a Adam Konkol był gitarzystą zespołu Łzy. Wydaje się, że gdyby Poświatowska nie doświadczyła poważnych problemów kardiologicznych, prawdopodobnie nie ujawniłaby talentu poetyckiego i literackiego. Jej życie wbrew pozorom trwało bardzo długo.

Ewa Joanna Marczak

„ŻyJe SIĘ tylko chwilę” — Did Halina Poświatowska Really Die Young?

Summary

The poet Halina Poświatowska for the most of her 32-years life overcame limitations associated with acquiring a mitral valve defect. She spent many months in hospitals, nursing homes and in the family home. In spite of common opinion she was not living for a very short time indeed when taking into account the state of cardiac surgery in the middle of the last century. The length of her life as a woman with serious heart defect, which caused additional complications in the functioning of the circulatory system, can not be compared to the life length of healthy people.

Słowa kluczowe: młodość, niepełnosprawność, Halina Poświatowska, wada serca

Keywords: youth, disability, Halina Poświatowska, congenital heart deseas

${ }^{34}$ K. Błażejowska, dz. cyt., s. 354. 